\title{
Diversity of Insecticidal Crystal Proteins (ICPs) of Indigenous Bacillus thuringiensis Strains
}

\author{
Ganga GC ${ }^{*}$, Charu Arjyal ${ }^{1}$, Yamuna Khadka ${ }^{1}$ and Sabina Dhamala ${ }^{1}$ \\ ${ }^{1}$ Tri-Chandra Multiple Campus, Ghanta Ghar, Kathmandu, Nepal \\ *Corresponding author: Ganga G.C, Tri-Chandra Multiple Campus, Ghanta Ghar, Kathmandu, Nepal; \\ E-mail: gangagc2@gmail.com
}

\begin{abstract}
Objectives: The purpose of this study was to characterize the indigenous Bacillus thuringiensis (Bt) isolated from the soil samples of Terai.

Methods: A total of 50 soil samples were collected from cultivated and barren fields of Terai region. Isolation was carried out using the acetate selection protocol Nutrient broth (NB) was acetated by using $0.25 \mathrm{M}$ sodium acetate which is a selective enrichment method for isolation of Bt. Characterization of the isolate was done by phenotyping methods (microscopy and biochemical).

Results: No distinct variation was observed between the isolates of cultivable and uncultivable lands. Bt were categorized into 7 different types based on colony morphology. The dominant colony was fried egg type identical with the reference strain, followed by flat white type of colony. The result showed that even though the colony morphology was same but the ICPs (Insecticidal crystal proteins) shapes produced by them varied, rod shapes $(53.57 \%)$, spherical $(10.71 \%)$, ovoid $(8.3 \%)$, amorphous (17.85\%), capheaded (9.5\%). ICPs morphology revealed the cry1, cry2, cry3, cry4, cry 8, cry 9, cry10 and cry 11 types of gene may be present in the native isolates.
\end{abstract}

Conclusion: This study represents the first report of several indigenous Bacillus thuringiensis strains with significantly different ICPs producing strains from hot tropical climate.

Key words: ICPs, amorphous, indigenous, microbial pesticides

\section{INTRODUCTION}

Biopesticides falls in major three categories Microbial pesticides, Plant pesticides, Biochemical pesticides (Çetinkaya, 2002; Kachhawa, 2017). They appear to be ecologically safer then commercial pesticides. Bt is a bacterium known for producing protein crystals with pesticidal properties. Bacillus thuringiensis biopesticide is commonly known as Bt (Jisha et al. 2013). Bt has been used commercially in the biological control of insect pests for the last 4 decades (Glare and Callaghan 1998). In Nepal farmers use chemical pesticides to control the pest of the crops. This is due to the unavailability of other agents to control the pest. These chemical pesticides are not specific and hazardous to the people and environment. The use of biopesticides in crop protection leads to

Date of Submission: November 13, 2018

Published Online: January 2019 decrease level of chemical pesticides in food chain and environment (Mishra et al. 2012). This study aims at isolating Bt from soil samples. There are a large number of toxins showing toxicity to one of many diverse pests produce by Bt. For these reasons there is current great interest in isolating novel strains of $\mathrm{Bt}$ with either unique host specificity or elevated toxicity so that it can be used in future as a biopesticide to control the pest of the crops. The genetic diversity and toxic potential of Bt strains differ from region to region (Hernández-soto et al. 2014). Bt strains have been collected and characterized in many parts of the country. But in case of Nepal the types of strain present in different region is not yet known. So the study aimed in collection and characterization of Bt found from the native soil of Nepal.

Date of Acceptance: December 8, 2018

DOI: https:/ / doi.org/10.3126/tujm.v5i0.22296 


\section{MATERIALS AND METHODS}

Sample collection: About $10 \mathrm{gm}$ of soil was collected from Terai region (Province No: 2 and 3) of Nepal. The sample was collected from the soil where but was not used in the past. Fifty soil samples were collected. Samples were collected by scraping of the surface soil material, and from 5cm depth (Barathi et al. 2012). All samples were aseptically placed in sterile plastic bags. Soil samples were collected from cultivable land and uncultivable land. Collected samples were stored at $4{ }^{\circ} \mathrm{C}$ before processing.

Isolation was carried out using the acetate selection protocol as described by Russell and Al 1987 with a slight modification. The nutrient broth was acetated by using $0.25 \mathrm{M}$ sodium acetate which is a selective enrichment method for isolation of Bacillus thuringiensis var Kurstaki, serotype 3a, 3b, 3c. Strain DOR Bt-1 was included in this study as a reference strain. To the sterile $9 \mathrm{ml}$ enriched media $1 \mathrm{~g}$ of soil sample was added and incubated overnight at $35^{\circ} \mathrm{C}$. After incubation the broth was heated at $100^{\circ} \mathrm{C}$ for 5 minute. Following heat treatment, the suspension was plated on nutrient agar plate (NA) by spread plate technique. The colony was enumerated, isolated and preserved in $60 \%$ glycerol containing NA as described by Ammouneh et al. 2011; Çetinkaya, 2002; Ralte et al. 2016 and stored at $4^{\circ} \mathrm{C}$ for further study.

Phenotypic characterization: The isolated organisms were identified by standard microbiological techniques including morphological, physiological and biochemical characteristics. The colony morphology was recorded by studying the shape, size, colony margin, opacity of the isolated colonies. Morphology of the vegetative cell, size, spore and crystal was studied by various staining technique like Gram staining, spore staining, negative staining, and Coomassie brilliant blue staining after incubation of culture for $72-90$ hours in a Nutrient broth. Physio-chemical characterization was done by biochemical test like, Indole test, MR test, VP test, citrate test, starch test, gelatin test, beta haemolysis test, sucrose, fructose, mannitol, lactose fermentation test, motility test and lecithinase test after incubation of the culture in the respective biochemical test media.

\section{RESULTS}

From the 50 soil samples collected from cultivable land and uncultivable land 84 isolates of Bt were obtained (Table 1).

Colony characterization: Bt showed different colony morphology in NA. On the basis of colony morphology the isolates were categorized into 7 different types. The dominant colony was fried egg type which was isolated from 50 soil samples followed by flat white type of colony, the colony code A resemble with the reference strain used in this study. On enumeration $10^{6} \mathrm{cfu} / \mathrm{gm}$ (colony forming unit) of soil Bt was obtained. The existing Bt showed biodiversity in morphology. On analysis of 25 samples from cultivable and 25 from uncultivable land Bt distribution in both types of samples was equal. There was no significant difference in the isolates obtained from both the soils (Table 2).

Microscopic characterization: The microscopic morphology reveals that they were Gram positive, spore producing and their vegetative size varies. For instance size of the vegetative cell of SN1 (1) by negative staining is $0.5 \times 0.1 \mu \mathrm{m}$ and the size of SN1 (3) $5 \times 2 \mu \mathrm{m}$.

Table 1: Distribution of Bt isolates in soil samples collected from different localities

\begin{tabular}{|c|c|c|c|c|}
\hline Province & District & $\begin{array}{l}\text { No of } \\
\text { samples }\end{array}$ & Sample coding & $\begin{array}{l}\text { No of } \\
\text { isolates }\end{array}$ \\
\hline \multirow[t]{3}{*}{$\begin{array}{l}\text { Province } \\
\text { No: } 3\end{array}$} & Sindhuli & 5 & $\begin{array}{l}\text { SN1(1), SN1(2), SN1(3), SN2(1), SN2(2), SN2(3), SN2(4), SN2(5), SN2(6), SN3(1), } \\
\text { SN3(2), SN3(3), SN4(1), SN4(2), SN5(1), SN5(2) }\end{array}$ & 16 \\
\hline & Chitwan & 4 & CW1(1),CW1(2),CW2,(1), CW2(2), CW3(1), CW4(1) & 6 \\
\hline & Makwanpur & 7 & MP1(1), MP1(2), MP2(1), MP3(1), MP3(3), MP4(1), MP4(2), MP5(1), MP6(1), MP7(1) & 10 \\
\hline \multirow{6}{*}{$\begin{array}{l}\text { Province } \\
\text { No: } 2\end{array}$} & Parsa & 6 & $\mathrm{P} 1(1), \mathrm{P} 1(2), \mathrm{P} 2(1), \mathrm{P} 2(2), \mathrm{P} 3(1), \mathrm{P} 4(1), \mathrm{P} 5(1), \mathrm{P} 6(1)$ & 8 \\
\hline & Bara & 6 & $\mathrm{~B} 1(1), \mathrm{B} 1(2), \mathrm{B} 1(3), \mathrm{B} 2(1), \mathrm{B} 3(1), \mathrm{B} 4(1), \mathrm{B} 5(1), \mathrm{B} 6(1)$ & 8 \\
\hline & Rautahat & 4 & $\mathrm{CHA} 1(1), \mathrm{CHA} 1(2), \mathrm{CHA} 2(1), \mathrm{CHA} 2(2), \mathrm{CHA} 3(1), \mathrm{CHA} 3(2), \mathrm{CHA} 4(1), \mathrm{CHA} 4(2)$ & 8 \\
\hline & Sarlahi & 6 & $\mathrm{~S} 1(1), \mathrm{S} 2(1), \mathrm{S} 2(2), \mathrm{S} 3(1), \mathrm{S} 3(3), \mathrm{S} 4(1), \mathrm{S} 4(2), \mathrm{S} 5(1), \mathrm{S} 6(1)$ & 9 \\
\hline & Mahottari & 6 & $M 1(1), M 1(2), M 1(3) M 1(4), M 2(1), M 2(2), M 3(1), M 4(1), M 5(1), M 6(1)$ & 10 \\
\hline & Dhanusa & 6 & D1(1), D1(2), D2(1), D2(2), D3(1), D3(2), D4(1), D5(1), D6(1) & 9 \\
\hline Total & & $\begin{array}{l}50 \text { soil } \\
\text { samples }\end{array}$ & & $\begin{array}{l}84 \mathrm{Bt} \\
\text { isolates }\end{array}$ \\
\hline
\end{tabular}


Coomassie brilliant blue staining (CBBS): The isolates were further analyzed by Coomassie brilliant blue staining (CBBS) technique for observing the presence of crystal protein and the shape of the crystal shows that even though the colony morphology was same but the ICPs shapes produced by them varied (Table
2). On calculating the types of ICPs produced by the 84 isolates in terms of percentage the highest prevalent ICPs was rod shaped crystal protein (Figure 1). In this study the rod shaped ICPs was found to be dominant. The rod shaped ICPs produced by the isolates were different (Table 2)

Table 2: Colony morphology of the native isolates

\begin{tabular}{|c|c|c|c|c|c|}
\hline S.No. & $\begin{array}{l}\text { Colony } \\
\text { code }\end{array}$ & Shape of the crystal & Morphology & $\begin{array}{l}\text { No. of } \\
\text { isolates }\end{array}$ & $\begin{array}{l}\text { cfu/gm } \\
\text { of soil }\end{array}$ \\
\hline 1 & A & Amorphous, rod shaped, ovoid, spherical & White, raised wavy (fried egg type) & 50 & $5 \times 10^{6}$ \\
\hline 2 & B & Long rod, short rod, spherical & White, flat, irregular & 23 & $5 \times 10^{6}$ \\
\hline 3 & $\mathrm{C}$ & Short rod shaped & Yellow, raised, smooth & 1 & $1 \times 10^{2}$ \\
\hline 4 & D & Short rod shaped & White, raised, round, smooth, mucoid & 1 & $1 \times 10^{1}$ \\
\hline 5 & $\mathrm{E}$ & Long rod & Shiny(watery type), raised, round & 1 & $1 \times 10^{2}$ \\
\hline 6 & $\mathrm{~F}$ & Rod shaped & White rhizoid type of colony & 1 & $1 \times 10^{2}$ \\
\hline 7 & G & Cap headed, spherical & white membrane slightly raised center & 7 & $3 \times 10^{4}$ \\
\hline
\end{tabular}

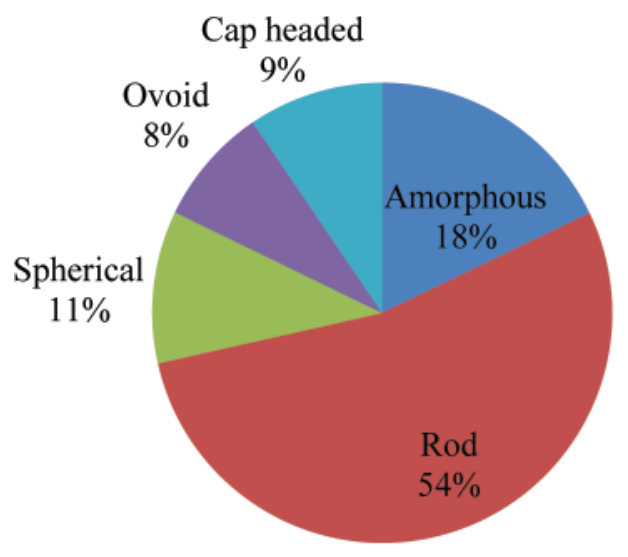

Figure 1: Distribution of ICPs\% in the native isolates

Based on ICPs morphology, the suspected cry gene cry 4, cry 8 cry 9 cry10 and cry11(Table3). present in the native isolates might be $c r y 1$, cry 2, cry 3 ,

Table 3: ICPs types, their percentage and suspected cry gene in 84 isolates

\begin{tabular}{llll}
\hline S.No. & ICPs shapes & ICPs\% & Suspected cry gene \\
\hline 1 & Amorphous & $17.85 \%$ & cry 4 cyt \\
2 & Rod & $53.57 \%$ & cry 1 \\
3 & Spherical & $10.71 \%$ & cry1, cry3, cry9, cry8 \\
4 & Ovoid & $8.3 \%$ & cry1, cry3, cry9, cry8 \\
5 & Cap headed & $9.5 \%$ & cry9 \\
\hline
\end{tabular}

Source for cry gene: Ibrahim et al. 2010; Lenina et al. 2014

The dominant colony was fried egg type photo $1 \mathrm{~b}$ and the flat white irregular type photola. 

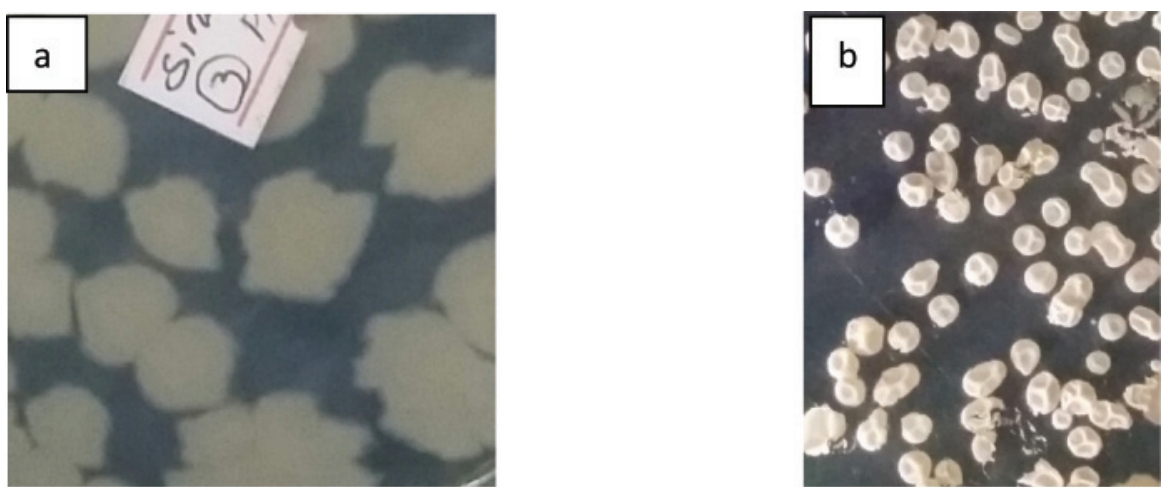

Photograph 1: Colony morphology of the native isolates a: SN1 (2) flat white irregular, b:ML5(1) fried egg type
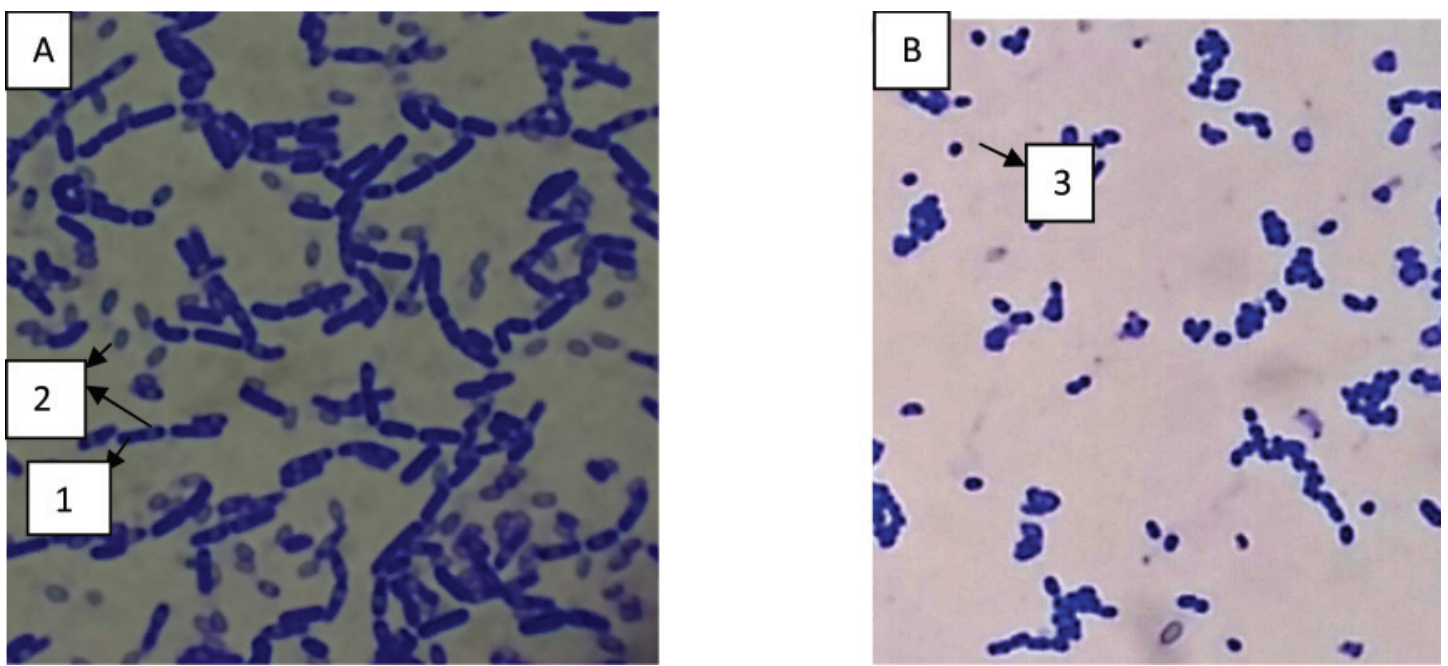

Photograph 2: Insecticidal crystal morphology. A) Spore attached and separated rod shaped crystal shapes.( 1: rod attached to the colourless spore rod is dark blue in colour. 2: colour less spores). B) 3: spherical spores

Biochemical profiling: Based on the biochemical characteristics all the isolates were positive for catalase, oxidase, starch, and gelatin hydrolysis, beta hemolytic, sucrose, fructose mannitol, lactose fermentation and lecithinase test but showed a variable reaction in Indole, MR, VP, Motility and citrate test.

\section{DISCUSSION}

Bacillus thuringiensis entomopathogenic pesticide has become as safe and successful microbial pesticide worldwide. In Nepal, in comparison with chemical pesticide the biopesticides are less commonly used due to the unavailability or unawareness. Screening the environment for a potent $\mathrm{Bt}$ strain for insect management has become necessary. In this study isolation of indigenous Bt was performed by collecting 50 soil sample from tropical region of Terai of province 2 and 3 (Table 1). Soil sample was collected from uncultivable and cultivable land; collected $10 \mathrm{~g}$ of soil was stored at $4^{\circ} \mathrm{C}$ before isolation. From the 50 soil samples 84 isolates of Bt strains were obtained. Similar type of result was also obtained by Ralte et al. 2016. There is no distinct variation in the isolates obtained from the cultivable and uncultivable land as well as the $\mathrm{cfu} / \mathrm{gm}$ of soil in both types of soil. This may be due to the sporulating capacity of Bt strain the spore can remain in a dormant stage until the favorable condition 
prevail. There was no significant difference in the isolates number as well as the colony type obtained from both type of soil. On enumeration the distribution of $\mathrm{Bt}$ in indigenous soil showed an average of $10^{6} \mathrm{cfu} / \mathrm{g}$ of soil. The colony morphology of Bt shows biodiversity in strain present in native soil.

The isolation technique used during the study period was effective for the isolation of $\mathrm{Bt}$ from the native samples. The enrichment was done in $0.25 \mathrm{M}$ sodium acetate broth for overnight at $35^{\circ} \mathrm{C}$ during this period the spores of Bt remain in dominant stage as the sodium acetate inhibit the germination of Bt spore, where as other spore forming Bacillus species germinate to produce vegetative cell. After incubation the broth was heat treated at $100^{\circ} \mathrm{C}$ for $5 \mathrm{~m}$ to kill the vegetative cell of other Bacillus species were as the spore of the Bt withstand the heating and on spreading on NA the spore of Bt germinated to produce a visible colony. As the selection process for isolation of Bt differed from the conventional methods used for isolation of spore forming bacteria, the new finding in this research work is heating the overnight incubated enrichment broth at $100^{\circ} \mathrm{C}$ for $5 \mathrm{~m}$ enhance the isolation of axenic culture of Bt strain. Heat treated at $80^{\circ} \mathrm{C}$ performed by others shows that the mix culture of Bacillus species isolation. So the heat shocked $100^{\circ} \mathrm{C}$ used for isolation is efficient to obtain the pure culture of Bt from soil samples, the reason behind the isolation may be due to the accumulation or synthesis of spore peptidoglycan which is different from the other Bacillus endospore producing bacteria. According to Peng et al. 2016 Bt endospore are encircled by an additional loose-fitting layer called the exosporium, which is not present on other species such as Bacillus subtilis, for which the coat constitutes the outermost layer of the mature spore. The exosporium is a balloon-like layer that acts as the outer permeability barrier of the spore and contributes to spore survival and virulence as it contains approximately 20 different proteins.

On observing the colony morphology of the 84 isolates, based on colony morphology the isolates are categorized into 7 different types (Table 2). The dominant colony type was fried egg type (A) Photograph 1(b). Which was present in 50 soil samples followed by flat white type of colony (B) Photograph 1(a).The phenotypic characterization based on morphology reveled that $\mathrm{Bt}$ strain of native soil shows a wide range of colony types. Some of the colony morphology (Table2) like (Yellow, raised, smooth, (White, raised, round, smooth, mucoid) (Shiny (watery type) raised, round) (White, rhizoid type of colony) (white membrane slightly raised center) this types of colony morphology was not found in all the soil samples. As well as they were not numerous as the other dominant types of colony code A and B. The colony code A was identical with the reference strain.

Characterization of Bt can be done in various ways such as biotyping, flagella serotyping, protein profiling, plasmid profiling, PCR amplification, molecular finger print etc. In this study isolated Bt strains were characterized by phenotyping methods like morphological and biochemical. The 84 isolates on Gram staining the microscopic morphology revels that they are rod shaped, Gram positive, the vegetative cell size differ among the isolates. The size variation determines that the native Bt strains differ in the capacity to produce different types of ICPS. On spore staining the native Bt isolates produced a central ellipsoidal spore on incubation in NB at $35^{\circ} \mathrm{C}$ for 72 hours. The 84 isolates were confirmed as Bt by detecting the crystal protein which was observed by coomassie brilliant blue staining (CBBS) technique. coomassie brilliant blue R-250 (CBB) is a popular and widely used dye for detection of proteins by gel electrophoresis. As the parasporal body or crystal protein of ICPS (insecticidal crystal protein) is made of protein compound which can be stained by $\mathrm{CBB}$ as dark blue color and the spore remain unstained and the vegetative cell takes up the light blue stain (Rampersad et al. 2002). The presence of insecticidal crystal protein (ICPS) in an 84 isolates proves that the native soil of Nepal posses diverse Bt subspecies with different ICPs (cry gene), thus the assessment of Cry proteins is a good basis to study insecticidal activity of $\mathrm{Bt}$ as well as assess the habitat containing a novel Bt strains. The authors Kebdani et al. 2016 could not discriminate between the two species until after the observation by scanning electron microscope, which allowed the visualization of the parasporal crystal which is present only in $B$. thuringiensis and responsible for entomopathogenic activity of this bacterium against several devastating 
species. Morphology of ICPS provides valuable information about the type of cry gene harboring $\mathrm{Bt}$ strain. In this study varied morphology of the ICPS was observed, the ICPs were characterized into 5 major groups' viz., amorphous, spherical, rod shaped (long rod, short rod), ovoid and cap headed, the bipyramid type of ICPs was not seen in this 84 isolates. This result is consistent with the result of Ralte et al. 2016 isolated two types of ICPs spherical and oval from 55 soil samples. According to Rana et al. 2002 only $8 \mathrm{Bt}$ strains from 350 soil samples collected from the five development region of Nepal produced bipyramidal ICPs and were effective against the cabbage butterfly, Pieris brassicae nepalensis and the cotton bollworm, Helicoverpa armigera Hubner, indicate the presence of few bipyramid ICPs in native soil. Based on the position of ICPs while observing in a microscope two different types of ICPs were observed viz., free ICPs and spore attached ICPs photograph2(A,B). Analysis of this ICPs in this 84 native isolates showed most of the ICPs were attached with the spore, the amorphous, rod shapes and cap headed. The SDS-PAGE analysis of spore coat profile carried by King et al. 2012 showed that spore coat of HD-1 and SN5 isolates spore coat contain Cry1 and Cry2 proteins. So the ICPs attached to the spore isolated from native soil sample may code for the Cry1 or Cry2 protein. B. thuringiensis strains can carry one or more cry genes, (Crickmore et al. 2014; Ibrahim et al. 2010) and therefore, they may synthesize one or more crystal protein. Diversity, distribution and abundance of cry gene type are dependent on the geographical area where $B$. thuringiensis strains were collected as well as the cultural condition provided may enhance in the isolation of organism with different ICPs producing isolates (Çetinkaya, 2002). According to Crickmore et al. 1998133 crystal proteins were categorized .

Based on the morphology of ICPs the indigenous Bt stains can be related to the type of cry gene present in it. The amorphous type of ICPs producing isolates may possess cry4 gene (Çetinkaya, 2002; Ralte et al. 2016) similarly spherical and ovoid related to cry1or cry3 or cry8 or cry9, (Ralte et al. 2016; Shishir et al. 2015). Rod shaped ICPs may be related to rectangular type according to other research articles that relates to cry1 gene (Çetinkaya, 2002). During this study the dominant type of ICPs was rod shaped in different size was observed. Cap headed related to cry9 gene. According Noguera and Ibarra 2010 B. thuringiensis shows great variability, as has been demonstrated by the huge number of strains isolated around the world by the number of serotypes known to date a total of 84 and by the great number of different cry gene sequences accumulated so far a total of 492 as well as by the number of molecular characterization tools that have been developed, such as sequencing of the flagellin gene and of the $g y r B$ genes, the band patterns from repetitive extragenic palindromic-PCR analyses, and the plasmid patterns, among others all indicating the great variability within this species. While many Cry proteins have useful pesticidal properties and may be exploited for the control of insect pest in agriculture (Palma et al. 2014). The reference strain used during the study Bacillus thuringiensis var Kurstaki, serotype 3a, 3b, 3c, Strain DOR Bt-1 also produced spherical type of crystal protein (Cry1). The parasporal crystal of Bt subsp. kurstaki HD-73 contains Cry1Ac protein only, whereas the parasporal crystal of HD1 strain, which belongs to the same subspecies, is comprised of five different Cry toxins Cry1Aa, Cry1Ab, Cry1Ac, Cry2Aa and Cry2Ab (Ibrahim et al. 2010). The spherical ICPs producing native $11 \%$ isolates may also posses Cry1 protein according to (Shishir et al. 2015). So the isolates with the spherical crystal protein may be $B$. thuringiensis subsps Kurstaki. For the identification of subspecies genotyping characterization has to be done, mainly the PCR methods for the detection of cry or cyt gene along with the SDS-PAGE may help in identifying the subspecies as well as the molecular weight of the crystal protein.

Biochemical profiling: Biochemical test was performed but it doesn't provide any evidence for the identification of Bt subspecies.on the basis of ICPS production by coomassie brilliant blue staining(CBBS) technique (Rampersad et al. 2002). According to Chen and Tsen 2002 when a large number of Bacillus strains was tested, results showed that discrimination between $B$. cereus and $\mathrm{Bt}$ is difficult to distinguish, a single feature, such as the presence of a ICPs or cry gene, may be reliable. One of the confidential methods to distinguish BT from other Bacillus spp is by observing the ICPs production 
by microscopy. Identification of cry gene content by PCR is the most effective techniques in screening large Bt.

\section{CONCLUSION}

This study revealed that several indigenous Bt strains with significantly different morphological and ICPs producing stains exists in hot tropical climate of Nepal. Some native Bt strain shows identical crystal protein with the reference strain. This shows the possibility of using natural bioinsecticides, based on the local strains of Bt.

\section{ACKNOWLEDGEMENTS}

The authors express sincere gratitude and heartiest honor to University Grants Commission, Sanothimi Bhaktapur for providing grant for this research. Also like to thank the Department of Microbiology, TriChandra Multiple Campus, Ghanta Ghar, Kathmandu, Nepal, for providing the laboratory facilities to carry the research successfully.

\section{REFERENCES}

Ammouneh H, Harba M, Idris E and Makee H (2011) Isolation and characterization of native bacillus thuringiensis isolates from Syrian soil and testing of their insecticidal activities against some insect pests. Turkish Journal of Agriculture and Forestry 35(4): 421-431.

Barathi S, Sangeetha P, Karthick C, Govindaraju S and PI A (2012) Diversity in Protein Profile of Bacillus thuringiensis Strains Isolated From Varied Soil Environments. Journal of Pharmacy Research 5(9): 4645-4647.

Çetinkaya F (2002) Isolation of Bacillus thuringiensis and Investigation of Its Crystal Protein Genes. A Dissertation Submitted to the Graduate School in Partial Fulfillment of the MASTER OF SCIENCE Department Biotechnology and Bioengineering Major B. Biotechnology and Bioengineering pp 62.

Chen ML, and Tsen HY (2002) Discrimination of Bacillus cereus and Bacillus thuringiensis with 165 rRNA and gyrB gene based PCR primers and sequencing of their annealing sites. Journal of Applied Microbiology 92: 912-919.

Crickmore N, Zeigler DR, Feitelson J, Schnepf E, Van
Rie J, Lereclus D, and Dean DH (1998) Revision of the nomenclature for the Bacillus thuringiensis pesticidal crystal proteins. Microbiology and Molecular Biology Reviews: MMBR, 62(3): 807813.

Crickmore N, Zeigler DR, Schnepf E, Vanrie J, Lereclus D, Baum J, Bravo A, Dean DH (2018) Bacillus thuringiensis toxin nomenclature. http://www. lifesci.sussex.ac.uk/Home/Neil_Crickmore/Bt/

Glare TR, and Callaghan MO (1998) Environmental and health impacts of Bacillus thuringiensis israelensis. Report for the Ministry of Health. Biocontrol and Biodiversity,Grassland Division,Ag Research Lincoln pp 5-10

Hernández-soto A, José RS, Rica C, Agronomía EDe, Agroalimentarias FDC, Rica UD and Rica C (2014) Diversity of Bacillus thuringiensis strains isolated from coffee plantations infested with the coffee berry borer Hypothenemus hampei. Revista Biologia Tropical 52(3): 757-764.

Ibrahim MA, Griko N, Junker M and Bulla LA (2010) A genomics and proteomics perspective. Bioengineered Bugs.

Jisha VN, Smitha RB, Benjamin S and Al ET (2013) An Overview on the Crystal Toxins from Bacillus thuringiensis. Advances in Microbiology 3: 462-472.

Kachhawa D (2017) Microorganisms as a biopesticides. Journal of Entomology and Zoology Studies 5(3): 468-473.

Kebdani M, Mahdjoubi M, Cherif A, Gaouar BN and Rebiahi SA (2016) Molecular characterization of local strains of Bacillus thuringiensis in the North of Algeria. African Journal of Microbiology Research 10(45):1880-1887.

King PJH, Ong KH, Sipen P and Mahadi NM (2012) Toxicity of local Malaysian Bacillus thuringiensis subspecies kurstaki against Plutella xylostella. African Journal of Biotechnology 11(56):11925-11930

Lenina NK, Naveen Ak, Sozhavendan AE, Balakrishnan N, Balasubramani V. Udayasuriyan V (2014) Characterization of parasporin gene harboring Indian isolates of Bacillus thuringiensis. Biotech 


\section{3(4): 545-551.}

Mishra J, Tewari S and Singh S (2012) Biopesticides: Where We Stand? Plant Microbes Symbiosis: Applied Facets 322-2068-8

Noguera PA, and Ibarra JE (2010) Detection of new cry genes of Bacillus thuringiensis by Use of a Novel PCR primer system. Applied and Environmental Microbiology 76(18): 6150-6155.

Palma L, Muñoz D, Berry C, Murillo J, Caballero P and Caballero P (2014) Bacillus thuringiensis toxins: An overview of their biocidal activity. Toxins 6(12): 3296-3325. https://doi.org/10.3390/ toxins 6123296

Peng Q, Kao G, Qu N, Zhang J, Li J and Song F (2016) The Regulation of Exosporium-Related Genes in Bacillus thuringiensis. ScientificReports 6: 1-12.

Ralte Z, Nachimuthu S and Guruswami G (2016) Diversity and toxicity of Bacillus thuringiensis from shifting cultivation (jhum) habitat. Biocontrol Science 21(2): 99-112.

Rampersad J, Khan A and Ammons D (2002) Usefulness of staining parasporal bodies when screening for Bacillus thuringiensis. Journal of Invertebrate Pathology 79(3): 203-204.

Rana P, Sijapati J, Rana N and Regmi C (2002) Distribution of Bacillus thuringiensis in the Soils of Nepal and Their Bioassay. Nepal Journal of Science and Technology 4: 27-31.

Russell S, and Al T E T (1987) Selective Process for Efficient Isolation of Soil Bacillus. Applied and Eniviromental/Microbiology 53(6): 1263-1266.

Shishir A, Akter A, Khan SN and Hoq MM (2015) Novel Toxicity of Bacillus thuringiensis Strains against the Melon Fruit Fly Bactrocera cucurbitae (Diptera: Tephritidae). Biocontrol Science 20(2): 115-123. 